Management Dynamics

Vol. 23, No. 2: 85-96, 2020

Shanker Dev Campus

Doi: https://doi.org/10.3126/md.v23i2.35811

\title{
Judicial Response to the Doctrine of Specific Performance in Nepal
}

Satya Narayan Kalika*

\section{Abstract}

Specific Performance is one of the equitable remedies available to the victim of breach of contract awarded by a judicial decision in cases where damages are not adequate. This paper aims to highlight the legal principles and provisions of specific performance; Nepalese laws in that arena; and most specifically the judicial response to the doctrine whereby several case laws where the order of specific performance was granted or refused by the Supreme Court of Nepal have been examined. This doctrinal study has adopted exploratory descriptive and analytical method. The analysis is based on primary data drawn from the statute and major judicial decisions, and some secondary data drawn from articles, books and treatises on the issue. The nascent Muluki Civil Code, 2074 has also provided various remedies available to the victim party of breach of contract like its predecessor legislation, i.e. the erstwhile Contract Act, 2056. This paper thrives to explore the principle of specific performance of contract and to discuss the judicial responses to the doctrine of specific performance of contract in Nepal.

Article Type: Research Paper

Key Words: Specific Performance, Judicial Response, Legal Remedy, Aggrieved Party

\section{Introduction}

Generally, each of the parties is responsible to perform their respective obligations under the contract. Where, parties are not responsible and aware of their obligations there exists a judicial procedure to enforce it. As a remedy to the breach of contract, the victim party is entitled to demand, inter alia, the performance of the promise in the court against the breaching party. There are two types of legal remedies available to the aggrieved party:

i. Equitable remedy: Specific Performance, Injunction.

ii. Therapeutic remedy: Rescission, Damage, Restitution, Quantum Merit, etc.

Specific performance is an equitable remedy available to the aggrieved party in case of a Breach of Contract, whereby a court issues an order requiring a party to perform a specific act under the contract. It is typically available in the sale of unique property in cases where the payment of damages is not an appropriate alternative.

* Lecturer, Shanker Dev Campus, Tribhuvan University;

E-mail:satya.kalika@sdc.tu.edu.np 
Mostly, the legal principles particularly in the law of contract are established through decisions of the court. The principle of Specific Performance is also the outcome of the court of equity (Chancery courts) in England \& Wales as are all the uniform rules of contract in common law are developed in England and Wales. Although Nepal has a hybrid legal system with inferences drawn from all kinds of legal systems such as common, continental and Hindu legal systems, it can be said that there is more impact of the Common Law System in the Nepalese Legal System in the present day, since the doctrine of stare decicis (to stand by things decided $)^{1}$ is prevalent in Nepal. It refers to the doctrine of binding precedent under which a court must follow the earlier judicial decisions when a similar issue arises in future. The doctrine is followed in Nepal whereby the decisions of the Supreme Court form binding precedents. ${ }^{2}$ Various legal principles concerning the specific performance of contract exist, which is one of the legal remedies available to the aggrieved party in a breach of contract. Thus, in this work, the researcher has attempted to explore and discuss analytically the responses of the Supreme Court of Nepal to the doctrine of Specific Performance.

\section{Statement of Problem}

As the legal principles concerning to law of contract established in England and Wales are studied and practiced in Nepal voluntarily, there may latent some problems in practice. Nepalese courts have been influenced by those legal principles of English law, where at times confusion may be created.

In this study, an analysis of major case laws concerning to the Specific Performance of contract has been done so as to clarify the response of Nepalese judiciary to the legal doctrine of Specific Performance. The questions raised in this brief research venture are: (i) what are the legal principles and provisions regarding Specific Performance of Contract? (ii) what are the judicial responses to the doctrine of specific performance in Nepal?

\section{Objectives of the Study}

The objectives of this study are:

i) To explore the legal principles and provisions on specific performance of contract,

ii) To discuss the judicial responses to the specific performance of contract in Nepal.

\section{Review of Literature}

The following literatures have been reviewed in the course of this study:

S.P. Koirala's article "The Remedy of Specific Performance under Contract Act, 2056"3 discusses various aspects such as legal remedies available in contractual issue, specific performance of contract, development of the issue, conditions to order or not to order for specific performance

1 Garner, B.A. (2009). Black's Law Dictionary (9th edn.), St. Paul: Thomson Reuters, 778.

2 Constitution of Nepal, Art. 128(4).

3 Koirala, S.P. (2012). The Remedy of Specific Performance under Contract Act, 2056 (Nepali Version). Business Law Journal, 20, 75-81. 
of contract and the concerned provisions in the Contract law. It also investigates issues like whether or not deed of advanced payment is a contract, whether or not a claim for property without registration is possible, interpretation of the law and enforcement and causes of dilemma and also provides the solution.

P. Baidya's article "Contract Law: Relationship with Immovable Property" ${ }^{4}$ highlights various definitions of contract contained in the Nepalese law of contract and precedents, as well as Indian and English Contract Law. He has focused his discussion on the cases decided after the enforcement of Contract Act, 2056 such as the case of Bir Shanker Kasai v. Anita Lama (2063), Prithvi Bahadur Maharjan v. Birat Bahadur Khadka (2064) as well, thereby serving as an important literature for this research venture.

In the article "Contract of Immovable Property and Existing Dilemma"5 the writer Judge Tek Narayan Kunwar who was then a Judge at Kathmandu District Court has focused on the issue 'whether a document is a valid contract or not'. Based on the decisions to some cases, the writer has discussed the perception of the Supreme Court on the concept of contract. He has discussed comparatively the case laws from Tirtharajkumari Rana v. Ram Shanker Shrestha to the case of Bir Shanker Kasai v. Amita Lama, as well as some provisions of the Contract Act, 2056 to determine whether contract for immovable property is prohibited or not. He concludes, (i) Contract Act, 2056 has to clearly incorporate the provision of Contract for immovable property, and (ii) the Supreme Court of Nepal also has to give way-outs in this regard in the course of adjudication of cases.

\section{Research Methodology}

Being a study of a qualitative nature, this research work is analytical, descriptive and is of doctrinal nature. The data used in this study are of primary and secondary sources. The secondary data of primary nature used in this study are derived from the statutory laws and precedents established by the Supreme Court of Nepal. As a qualitative study, this is focused deep into the facts of the case laws, issues raised by the plaintiff and the basis of the decision. Similarly, the secondary data of qualitative nature are derived from books, articles and commentaries published in the law journals. The method of citation used in this work is APA method with footnotes, as done in legal research.

This study is limited to the principles, legal provisions and judicial responses relating to specific performance of contract within Nepal. It deals with the exploration of the concerned legal principles and analyses of the judicial responses to the specific performance of contract.

4 Baidya, P. (2068). Contract Law: Relationship with Immovable Property. Nyayadoot Bimonthly, 43(1), 201.

5 Kunwar, T.N. (2068). Contract of Immovable Property and Existing Dimemma (Nepali Version). Kanoon Bimonthly, 87. 


\section{Theoretical Underpinnings and Statutory Provisions}

\section{Legal Remedies Available to the Aggrieved Party}

Where the contract is breached by one of the parties the other party becomes aggrieved financially. In such a case, Part-5, Chapter-5 of the Muluki Civil Code, 2074 provides the following remedies: Rescission, Suit for Damage of loss, Suit for Restitution, Suit for Quantum Meruit, Suit for Injunction and Suit for Specific Performance. This last issue is dealt in this research venture.

These legal remedies available to the aggrieved party can be categorized into two groups- (i) Therapeutic remedy, and (ii) Equitable remedy:

Types of Remedies available to the victim party of breach of contract:

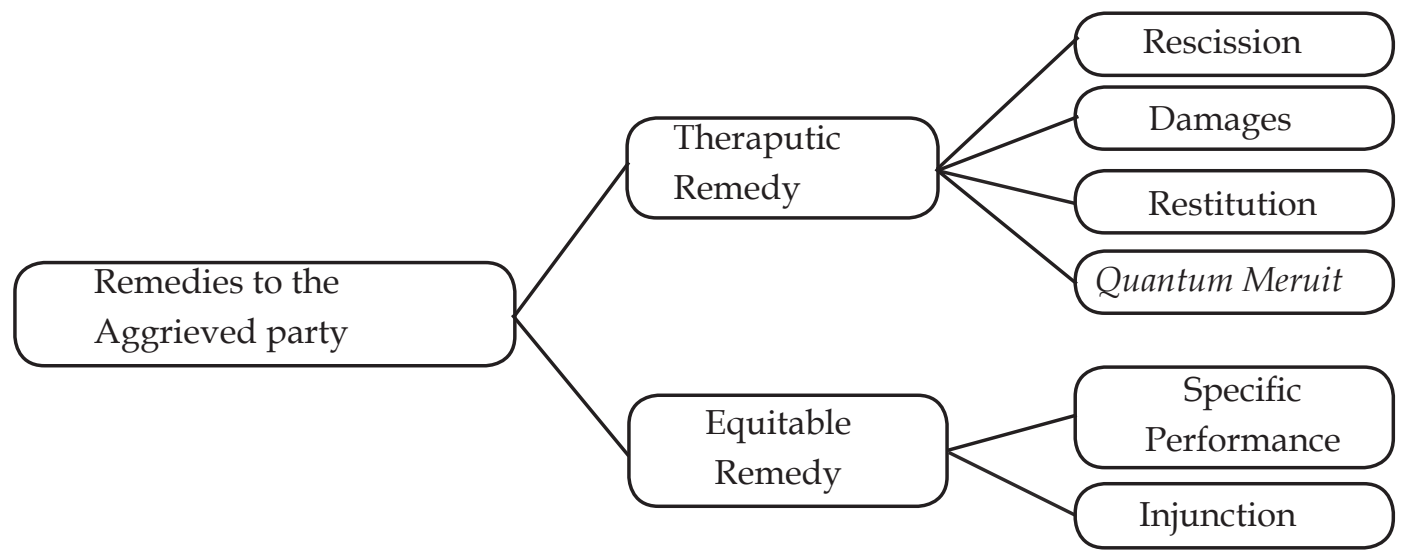

\section{Laws on Specific Performance of Contract}

Specific performance of contract is one of the legal remedies available to the aggrieved party in case of breach of contract. Such an order is made by the court when other remedies are inadequate and unreasonable. ${ }^{6}$ Black's Law Dictionary contains, "Specific performance is an equitable remedy that lies within the court's discretion to award whenever the common law remedy is insufficient, either because damages would be inadequate or because the damages could not possibly be established. Specific performance is a court-ordered remedy that requires precise fulfilment of a legal or contractual obligation when monetary damages are inappropriate or inadequate, as when the sale of real estate or a rare article is involved.

In the Nepalese context, legal frameworks for the specific performance are provided in the Muluki Civil Code, 20747. It reads, "In case cash compensation paid in consideration of the actual loss or damage suffered by the aggrieved party as a result of breach of contract is not reasonable or adequate, the aggrieved party may demand the execution of the contract as

6 Kalika, S.N. (2013). The Law of Contract, Kathmandu: Pairavi Prakashan, 141.

7 Muluki Civil Code, 2074, Section 540 (1)(2)(a-e). 
stipulated specific performance instead of making a claim for compensation". This is similar to the provisions in the erstwhile Contract Act, 2056 and the Act Relating to Contract, 2023.

In case any party to a contract does not meet liability under the contract, or gives a notice to the other party that he/she will not perform the work to be performed under the contract, or in case his/her action or conduct shows that he/she is incapable of performing the work under the contract, he shall be deemed to have breached the contract. ${ }^{8}$ In case a party has breached the contract under Section 535 (1), or in case his/her action or conduct shows that he/she has not basically complied with the contract; the other party shall not be compelled to perform the contract, and may cancel the contract by furnishing a notice thereof to the other party.

\section{Development of the Principle of Specific Performance of contract}

Compensation to the victim party in case of loss by breach of contract was derived from Roman law, one of the sources of English law. There was no practice of concept of specific performance under the equity and conscience in English Common Law system. Afterwards, the legal remedy on the basis of equity and conscience was started by the Court of Chancery (Equity Court); contract was enforced by the chancery court and regarded as a personal liability. Contract was the basis of property transaction.

In Nepal, the Muluki Ain, 2020 (Chapter on General Transaction (Lenden Byabaharko Mahal)) had incorporated this principle. Later, the Act Relating to Contract, $2023^{9}$ and the Contract Act, $2056^{10}$ also contained provisions relating to the principle of specific performance of contract. Although the 2023 Act did not contain as clear and as succinct provisions in that regard as the Contract Act, 2056 did and the prevailing Muluki Civil Code, 2074 does, yet the cases were decided on the basis of Section 10 (1) of the Act, for instance, in the case of Tirtharajkumari Rana v. Ramshanker Shrestha. The prevailing Muluki Civil Code, 2074 also contains the provisions on the specific performance of contract.

The Code reads, "in case the cash compensation paid in consideration of the actual loss or damage suffered by the aggrieved party as a result of breach of contract is not reasonable or adequate, the aggrieved party may demand the execution of the contract as stipulated specific performance instead of making a claim for compensation" ${ }^{11}$ Nepalese law of contract is made up of customs, statutes, universal principles and judicial decisions (precedents) of the Supreme Court. In this context, this study focuses on the legal principles established by the judicial decisions of the Supreme Court of Nepal with regard to specific performance.

8 Muluki Civil Code, 2074, Section 535(1).

9 See, erstwhile Act Relating to Contract, 2023, Section 10(1).

10 See, erstwhile Contract Act, 2056, Section 86(1)(2)(a-e).

11 Muluki Civil Code, 2074, Section 540(1). 
4. Conditions to make an order a Specific Performance of Contract ${ }^{12}$

Specific Performance is a unique and a kind of 'privileged' remedy, which can be ordered only if monetary compensation is not reasonable and adequate for the actual loss or damage suffered by the aggrieved party, and if the aggrieved party demands a specific performance of contract instead of compensation, and if the Court at its discretion decides to give such order.

\section{Conditions for Not to make an Order the Specific Performance of Contract ${ }^{13}$}

Notwithstanding anything stated above, the order of specific performance may not be given in any of the following circumstances: i) If monetary compensation is an adequate remedy for the breach of contract; ii) If the court cannot supervise the performance of the act under the contract; iii) If the contract is for providing services of personal ability, skill or knowledge; iv) If the contract cannot specifically be performed; and v) If the party in breach of the contract claims for its specific performance.

\section{Results and Discussions: \\ Exploration and Judicial Responses to the Specific Performance}

\section{Role of the Judiciary on Specific Performance}

Judiciary is one of the three organs of the state. It discharges functions of adjudicating cases with the power conferred by the Constitution and based on the spirit of its provisions, concerned laws and recognized principles of justice, such as equity and conscience. Issues/ disputes concerning to the performance of contract are one of the most important sectors in mercantile law. The Supreme Court has been establishing some landmark precedents while deciding cases relating to enforcement of contractual obligations by the parties, particularly after the entry into force of the Act Relating to Contract, 2023.

2. Exploring the major cases decided by the Supreme Court and their Analyses:

The following cases are concerned to the principles of specific performance.

12 Muluki Civil Code, 2074, Section 540(1)(2).

13 Muluki Civil Code, 2074, Section 540(2)(a-e) 
Major cases responded by the Supreme Court of Nepal:

\begin{tabular}{|l|l|l|l|}
\hline S.N. & Plaintiff & Defendant & Citation \\
\hline 1. & Mahanta Singh Thakuri & Shekharnath Acharya & NKP 2040, Vol. 3, p. 65 \\
\hline 2. & Shantidevi Shah & Arjunjung Shah & NKP 2040, Vol. 4, p. 161 \\
\hline 3. & Dr. Badriraj Pandey & Navraj Koirala & NKP 2044, Vol. 3, p. 277 \\
\hline 4. & Sarki Kami & Kanchho Kami & NKP 2048, Vol. 9, p. 546 \\
\hline 5. & Tirtharajkuamari Rana & Ramshanker Shrestha & NKP 2049, p. 1 \\
\hline 6. & Dhanmaya Maharjan & Tulasi Maharjan & NKP 2062, p. 1008 \\
\hline 7. & Ram Krishna Thapa & Rhododendron High School & NKP 2058, p. 200 \\
\hline 8. & Bir Shanker Kasai & Anita Lama & NKP 2063, p. 395 \\
\hline 9. & Jayalal Subedi & Lal Bahadur Khatri & NKP 2063, p. 7776 \\
\hline 10. & Prithvi B. Maharjan & Birat Bahadur Khadka & NKP 2064, p. 1100 \\
\hline 11. & Lalan P. Shah & Parsa DDC & NKP 2066, p. 1535 \\
\hline 12. & Rojer Henke & Sharada Prasain & NKP 2070, p. 288 \\
\hline 13. & Pradipraj Pandey & Karmalaxmi Kansakar & NKP 2072 p. 510 \\
\hline 14. & Prithvirasad Roka & Vinod Mohan Acharya & NKP 2072, p. 1163 \\
\hline
\end{tabular}

Source: Nepal Kanoon Patrika, different issues

\section{Judicial Responses to the major cases filed in the court demanding the order of Specific Performance of Contract}

Mahanta Singh Thakuri v. Shekharnath Acharya (2040): ${ }^{14}$ This case has established the principle that the deed of advanced payment is regarded as a document of contract, where the document fulfills essential elements of an enforceable contract. The deed of advanced payment is concluded between the parties to insure for the sale and purchase of a particular land and building. Though the term 'deed of advanced payment' is mentioned, the nature of the deed has contained fundamental elements of a contract, and the promisor party has to transfer the immovable property, e.g. land or building.

Though this case was decided in 2043/9/18 by the full bench of the Supreme Court of Nepal, the King had ordered a Hukum Pramangi (order of the King) for revision (dohoryai paun) in accordance with the provision of the Constitution of Nepal, $2019^{15}$ and was thus presented before a full bench of the Court again. Then, the full bench made a clear definition of the contractual obligation and order of specific performance of the contract.

The verdict has contained that there are two things to be considered before deciding whether the document is of contractual nature or not: (i) whether the deed has obliged two or more parties to perform or not to perform any act or not? and (ii) whether there is meeting of minds between two parties to do the act prescribed in the contract or not? The decision clears that

14 Mahanta Singh Thakuri v. Shekharnath Acharya, NKP 2040, 165.

15 Constitution of Nepal, 2019, Article 72(b). 
the deed of purchase and sale of an immovable property is not the deed of 'sale'; it is the deed of 'agreement to sell'. It means 'Sale' and 'agreement to sell' are in different legal status.

Shantidevi Shah v. Arjunjung Shah (2040): ${ }^{16}$ This initial case has focused on the performance of the contract. The liable party has to specially perform the promise to pay the amount within the time given, as the promise was not countered by the promised. It was under the definition of the then the Act Relating to Contract, 2023, Section 2(a). Thus, in the light of jurisprudence of contractual liability, the promisor was obliged to fulfil the promise towards the promise party.

Dr. Badriraj Pandey v. Navraj Koirala (2044): ${ }^{17}$ In this, case, it has been established that it is the authority/jurisdiction of the court to execute the contractual liability and impose upon the liable parties. The promise made for the transfer of land under the law of land is directed to the promisor party.

Sarki Kami et .al. v. Kanchho Kami (2048): ${ }^{18}$ This case has established legal principles and focused on the essentials for a contract. Whatever the name given to a deed, if that fulfills all essentials to a contract in accordance to the Act Relating to Contract, 2023, that document is regarded as contract. Such deed is not necessary to register in accordance to Section-1 of the Chapter of Registration of Muluki Ain. The court has issued an order for specific performance as it is considered a valid deed in accordance to Section 24 of Chapter on Court Proceedings of the Muluki Ain.

Tirtharajkumari Rana v. Ramshanker Shrestha (2049): ${ }^{19}$ This is a leading case law pertaining to the law of contract. This judgment has established various precedents, such as - essential elements of a valid contract, format of a contract, nature of the deed, obligations created by a contract and the deed of transfer of immovable property is recognized as a contract and court made an order for specific performance of contract between the parties. There was an agreement to sell an immovable property and a deed of advance payment (Bainabattako Likhat) was made. Based on the deed, the victimized party filed a case in the court demanding for specific performance to sell of a piece of land. The court granted specific performance.

Dhanmaya Maharjan v. Tulasi Maharjan (2062): ${ }^{20}$ This case has given a clear order that the promisor or the defendant party has to fulfill the promise as per the contract. There was a contract document of advanced payment for the transfer of ownership of land within fifteen

16 Shantidevi Shah v. Arjunjung Shah NKP 2044, 716.

17 Dr. Badriraj Pandey v. Navraj Koirala, NKP 2044, 277.

18 Sarki Kami et. al. v. Kanchho Kami, NKP 2048, 546.

19 Tirtharajkumari Rana v. Ramshanker Shrestha, NKP 2049, 1.

20 Dhanmaya Maharjan v. Tulasi Maharjan, NKP 2062, 1008. 
days. The petitioner has demanded to perform the promise as specific in the Contract in accordance to the Act Relating to Contract, the defendant party has to transfer the land prescribed in the contract as promised in the contract.

Ram Krishna Thapa v. Rhododendron High School (2058): ${ }^{21}$ In this case, too, an order for specific performance of contract has been issued by the court. The verdict given by the subordinate courts appears harmonious; therefore, the land prescribed in the contract has to be transferred to the claimant/plaintiff by the defendant as the liability of the parties to a contract is obligatory. The decision contains that it is certain that performance of promise by the concerned parties to a contract is natural.

Besides these cases more than a dozen of case laws are in harmony of order of specific performance of contract. The court has issued an order of specific performance to the defendant or breacher party in the protection of the interest of aggrieved party. However, a turning point in the judicial trend comes by the Supreme Court of Nepal from the case of Bir Shanker Kasai $v$. Anita Lama. ${ }^{22}$ The verdict given in this case became contradictory. In the case of Bir Shanker Kasai, there was a contract for the transfer of immovable property (land) between two parties. The court interpreted that a contract for sale of immovable property is not possible on the ground of Section 40 (1) of the Contract Act, 2056. The Section contains that Contract of sale of goods is regulated by this section it is the special contract under which movable properties can be dealt by this section. The general law of contract may deal with ay types of transaction concluded between the parties, but it is not provided in the Act.

However, the petitioner of this case has not claimed for order of specific performance but instead has claimed for damages of loss. This verdict has given an order of restitution of the money transacted under the deed of advanced payment. In the same line, other cases are also decided by the Supreme Court of Nepal, such as: Jayalal Subedi v. Lal Bahadur Khatri, ${ }^{23}$ Prithoi Bahadur Maharjan v. Birat Bahadur Khadka, ${ }^{24}$ etc.

Lalan P. Shah v. Parsa DDC (2066)::25 In Lalan P. Shah v. Parsa District Development Committee Office, Birgunj, Parsa, the Supreme Court held that the order of specific performance of contract cannot be granted in case if the contract which was claimed to be breached was signed for providing services relating to personal expertise, skill or knowledge, which was also provided in Section 86 (2) (c) of the then Contract Act, 2056.

21 Ram Krishna Thapa v. Rhododendron High School, NKP 2058, 200.

22 Bir Shanker Kasai v. Anita Lama, NKP 2063, 395.

23 Jayalal Subedi v. Lal Bahadur Khatri, NKP 2063, 7776.

24 Prithvi Bahadur Maharjan v. Birat Bahadur Khadka, NKP 2064, 1100.

25 Lalan P. Shah v. Parsa DDC, NKP 2066, 1535. 
The Court held the service given by the legal advisor as a service given on the basis of personal knowledge and skill, and that when the legal advisor denies to provide service to the beneficiary as per the contract, the order of specific performance cannot be granted. It upheld the decision of the Court of Appeal, Hetauda which had denied the order of specific performance.

Rojer Henke (Sumit Hotel Pvt. Ltd.) v. Sharada Prasain, et. al. (2069): ${ }^{26}$ In this case, the District Court had granted an order of specific performance which was quashed by the Court of Appeal, Patan on grounds that the breacher party of the contract himself had demanded a specific performance of contract, which was contrary to Section 86 (2) (e) of the then Contract Act, 2056. The Supreme Court upheld the decision of the Court of Appeal, thereby denying rendering the order of specific performance in this case.

Pradipraj Pandey v. Karmalaxmi Kansakar (2071): $:{ }^{27}$ In this case, inter alia, it was discussed that the doctrine of Specific Performance was a remedy only in lieu of damages, and that the contract frustrates only when it is impossible to perform the contract due to natural or other reasons, and cases where the contract was breached not due natural or other reasons but by the party himself or herself, as in this case, cannot come under the doctrine of frustration of contract, and therefore the order of specific performance can be granted. The Supreme Court upheld the decision of the lower courts to grant specific performance.

Prithvirasad Roka v. Vinod Mohan Acharya, Campus Chief of Jaljala Multiple Campus, Liwang, Rolpa (2072): ${ }^{28}$ In this case, the Supreme Court held that although the remedy of Specific Performance can be granted by the order of the court, the remedy can be sought only during the validity or term of the contract. On the ground of the term of the contract had already expired, the Supreme Court upheld the decision of Court of Appeal, Tulsipur, which had denied the order of specific performance and had quashed the petition.

This case is another example which shows the strict approach taken by the the courts in regard to rendering an order of specific performance.

\section{Conclusion}

Specific Performance of Contract is an order of the court for compulsory enforcement of the contract concluded between the parties in case of breach of promise, whereby monetary compensation is not adequate, and the sold property is of specific nature. This principle is also incorporated in the Nepalese law of contract and as well as is practiced in the Nepalese courts

26 Rojer Henke authorized by Sumit Hotel Pvt. Ltd., Kupandole v. Sharada Prasain, et. al., NKP 2070, at 288.

27 Pradipraj Pandey v. Karmalaxmi Kansakar, NKP 2072, 510.

28 Prithvirasad Roka v. Vinod Mohan Acharya, Campus Chief of Jaljala Multiple Campus, Liwang, Rolpa, NKP 2072, 1163. 
of law. Nepalese courts have taken a heedful approach with respect to rendering orders for specific performance and are quite vigilant in that regard. One can witness that an order of specific performance of contract has been granted as a remedy only in a very few cases of breach of contract, specifically in cases where no other remedies are available, or, even if available, are not adequate. Therefore, the judicial response to the specific performance of contract in Nepal is watchful, infrequent, and discretionary, and the courts grant this remedy to the aggrieved party when other alternatives are not sufficient or reasonable, and that too, not as a matter of right of the party but as a matter of discretion of the bench.

\section{References}

Baidya, P. (2068). Contract Law: Relationship with Immovable Property. Nyayadoot Bimonthly, 43(1), 201.

Bir Shanker Kasai v. Anita Lama, NKP 2063, 395.

Constitution of Nepal, 2019, Kathmandu, LBMC.

Contract Act, 2056, Section 86 (1)(2)(a-e), Kathmandu, LBMC.

Dhanmaya Maharjan v. Tulasi Maharjan, NKP 2062, 1008.

Dr. Badriraj Pandey v. Navraj Koirala, NKP 2044, 277.

Garner, B. A. (2009). Black's Law Dictionary (9 ${ }^{\text {th }}$ edn.), St. Paul: Thomson Reuters, 778.

Jayalal Subedi v. Lal Bahadur Khatri, NKP 2063, 7776.

Kalika, S. N. (2013). The Law of Contract, Kathmandu: Pairavi Prakashan, 141.

Koirala, S. P. (2012). The Remedy of Specific Performance under Contract Act, 2056 (Nepali Version). Business Law Journal, 20, 75-81.

Kunwar, T. N. (2068). Contract on Immovable Property and Existing Dilemma (Nepali Version). Kanoon Bimonthly, 87, 8-10.

Lalan P. Shah v. Parsa DDC, NKP 2066, 1535.

Mahanta Singh Thakuri v. Shekharnath Acharya, NKP 2040, 165.

Muluki Civil (Code) Act, 2075, Kathmandu, LBMC.

Pradipraj Pandey v. Karmalaxmi Kansakar, NKP 2072, 510.

Prithvi Bahadur Maharjan v. Birat Bahadur Khadka, NKP 2064, 1100.

Prithvirasad Roka v. Vinod Mohan Acharya, Campus Chief of Jaljala Multiple Campus, Liwang, Rolpa, NKP 2072, 1163.

Ram Krishna Thapa v. Rhododendron High School, NKP 2058, 200. 
Rojer Henke authorized by Sumit Hotel Pvt. Ltd., Kupandole v. Sharada Prasain, et. al., NKP 2070, 288.

Sarki Kami et. al. v. Kanchho Kami, NKP 2048, 546.

Shantidevi Shah v. Arjunjung Shah, NKP 2044, 716.

The Act Relating to Contract, 2023, Section 10(1), Kathmandu, LBMC.

Tirtharajkumari Rana v. Ramshanker Shrestha, NKP 2049, 1. 